\title{
PENGELOLAAN BUDIDAYA NILAM (POGESTEMON CABLIN BENTH) DAN PENYULINGAN ATSIRI PADA KELOMPOK TANI DESA BANJARAN DI HUTAN LINDUNG REGISTER 20 PESAWARAN LAMPUNG
}

\section{PATCHOULI PLANTS MANAGEMENT AND ESSENTIAL OIL VOLATILITY ON FARMERS GROUP AT CONSERVATION AREA}

\author{
Oleh: \\ M.Tahir, Suprapto, Dewi Riniarti, Ersan \\ Politeknik Negeri Lampung \\ Email: m_tahir_mandar@yahoo.co.id/tahir@polinela.ac.id
}

\begin{abstract}
Community service program (PPDM) was carried out on Tunas Muda farmer groups, Rente Rejo 1 and Rente Rejo 2. The general purpose of this activity was to provide an added value to the community of protected forest areas by utilizing patchouli from mutation breeding. To preserve the forest, efforts should be made to utilize forest land under tree stands with shade-tolerant plants. The implementation of patchouli cultivation was carried out phasing activities, namely tillage, construction of nursery buildings, procurement of cuttings, nursery maintenance, making planting beds in the field, maintenance with fertilization, weed control, pest control, and harvesting and harvest time . For training activities, implementation has been carried out in the form of direct practice in the field based on cultivation activities. The yield of essential oils obtained by yield between 2.14 - 3.10 percent. Furthermore, the evaluation results show that the average farmer understanding of cultivation activities at the beginning of the new activity reaches $34.21 \%$ and the end of the activity has reached 100\%. This is supported by chi squared analysis with a value of 5.36 and t table 3.48 of the test level of 5\%. The level of income of farmers obtained for one hectare is Rp. 58,750,000.00 for six months or Rp. 9,791,000 / month / ha. This service program (PPDM) illustrates that intensive and measurable mentoring can improve farmers' knowledge in practicing patchouli cultivation with maximum sustainability.
\end{abstract}

Keywords: Patchouli plants, conservation area, good agricultural practises, essential oil.

\section{PENDAHULUAN}

Desa Banjaran Kecamatan Padang Cermin Kabupaten Pesawaran, mata pencaharian penduduknya adalah petani $90 \%$, dan $10 \%$ pedagang, pegawai negeri, pertukangan dan buruh pabrik, dengan jumlah penduduk 4.266 jiwa, yaitu 2.218 laki-laki dan 2.048 perempuan. Adapun desa berada pada kawasan hutan register 20 dibawah pengawasan KPHL Pesawaran. Pengelolaan hutan lindung tersebut berdasarkan Surat Perintah Bupati Pesawaran No.800/389/SP/IV.03/2013 tanggal 31 Oktober 2013, Wilayahnya terletak pada $5^{\circ} 07^{\prime} 30$ " s.d 5 $48^{\prime} 15$ " LS dan $104^{\circ} 56^{\prime} 15^{\prime}$ ' s.d $105^{\circ} 11^{\prime} 15^{\prime}$ ' BT, elevasi 0-1.604 mdpl, tofografi datar hingga berbukit, curah hujan tertinggi bulan Desember $424,50 \mathrm{~mm}$ dan 23 hari hujan. Jenis tanah Regosol, Gleisol, Kambisol, Podsolik. Tata Hutan seluas 
10,903 ha, yaitu HL Reg. 20 Pematang Kubuato seluas 7,050 Ha, HL. Kawasan hutan dikelolah masyarakat dengan budidaya. Pembukaan hutan untuk areal budidaya, penebangan pohon untuk kebutuhan perumahan tanpa memperhatikan fungsi ekosistem/hidrologis, sehingga fungsi hutan untuk ekosistem mengalami degradasi lahan dan hutan. Adanya praktik penyalagunaan hutan dan pola bertani tersebut, diperlukan upaya agar deforestasi hutan ke non hutan dihentikan melalui program pembudidayaan tanaman nilam tanpa merusak tanaman hutan, dengan upaya tersebut kualitas hutan dan penurunan emisi gas rumah kaca melalui rehabilitasi lahan dan hutan dapat diminimalkan (Monografi KPHL Pesawaran, 2014).

Pengusahaan budidaya nilam yang dilaksanakan oleh petani masih menggunakan klon lokal serta praktik budidaya yang belum optimal, akibatnya produksi yang diperoleh rendah, hingga saat ini (tahun tanam akhir musim hujan tahun 2013) produksi berat basah yang dicapai rata-rata $3.500 \mathrm{~kg} / \mathrm{ha}$, sedang hasil penelitian dengan iradiasi sinar gamma dan spesifik lokasi dengan naungan di atas 15 ton/ha/musim (Tahir, 2015) dan (Tahir dkk, 2017). Melihat fenomena tersebut perlu upaya agar animo masyarakat dalam mengusahakan budidaya nilam tidak mengalami kemunduran dan penghentian usaha, yaitu dengan penyuluhan dan Demplot (Demonstrasi Plot) hal tersebut dimaksudkan agar petani dapat belajar sambil bekerja. Untuk mengoptimalkan pengelolaan kawasan hutan lindung dilaksanakan inventarisasi pengelolaan budidaya dan analisis situasi dengan model SWOT untuk memecahkan solusi perbaikan budidaya dan kelestarian hutan. Analisis SWOT yang dimaksud meliputi penilaian peluang internal dan eksternal dalam rangka pengembangan kegiatan secara terarah.

\section{METODE PENGABDIAN}

\section{Tahapan Kegiatan}

Pelaksanaan kegiatan pengabdian kepada masyarakat ini meliputi:

1. Kegiatan penjajakan dan pengurusan izin, meliputi survey awal dan perizinan terhadap aparat setempat.

2. Penyiapan sarana kegiatan, berupa persiapan bahan dan alat teknis kegiatan berupa demplot dan bahan tanam.

3. Pengadaan klon nilam, yang berasal dari hasil penelitian.

4. Perakitan alat suling, meliputi pembuatan ketel suling dan kondensor, dan

5. Pelaksanaan pelatihan budidaya tanaman dan demonstrasi plot budidaya tanaman, pengadaan dan persiapan brangkasan untuk disuling, dan penyulingan,

Seluruh rangkaian kegiatan tersebut telah dimulai dari bulan Februari samapai dengan September 2018. Adapun tahapan program PPDM tersebut dilaksanakan, meliputi demplot klon nilam, praktek baik budidaya, praktek baik penyulingan, penyulingan nilam, dan penyuluhan.

Khalayak sasaran kegiatan ini adalah kelompok tani Tunas Muda, Rente Rejo 1 dan kelompok tani Rente Rejo 2 yang anggota terdaftar masing-masing 20 kepala keluarga.

\section{Evaluasi Pelaksanaan}

Evaluasi kegiatan akan dilakukan dalam tiga bentuk, yaitu evaluasi awal, evaluasi proses, dan evaluasi akhir kegiatan. Evaluasi awal berupa pre test, yang diukur dengan memanfaatkan kuesioner terstruktur dan diberikan kepada seluruh peserta penyuluhan. Hasil pengukuran tersebut menjadi titik awal dalam menentukan ruang lingkup materi yang diberikan. Evaluasi proses dilakukan saat kegiatan berlangsung, dimana indikatornya adalah seluruh peserta mampu untuk melaksanakan tahapan kegiatan secara baik dan 
selesai. Adapun evaluasi akhir dilakukan dengan membandingkan pengetahuan awal dan pengetahuan akhir dari para peserta melalui uji Chi Kuadrat.

\section{HASIL DAN PEMBAHASAN}

Hasil penilaian rata-rata pengetahuan petani peserta PPDM sebelum pelaksanaan program baru mencapai $34,21 \%$ dan setelah pelaksanaan meningkat mencapai $100 \%$ yang disajikan pada Tabel 1.

Tabel 1. Gambaran Pemahaman Petani Peserta PPDM Terhadap Pengelolaan Tanaman Nilam

\begin{tabular}{llcc}
\hline No & Gambaran Umum & $\begin{array}{c}\text { Sebelum Pelaksanaan } \\
\text { PPDM (\%) }\end{array}$ & $\begin{array}{c}\text { Setelah Pelaksanaan } \\
\text { PPDM } \\
(\mathbf{\%})\end{array}$ \\
\hline 1 & Mengenal Tanaman Nilam & 100 & 100 \\
2 & Pengetahuan Budidaya & 15 & \\
3 & Pelaksanaan Budidaya & & 100 \\
& - Waktu Tanam & 9,0 & 100 \\
& - Pembibitan & 15,3 & 100 \\
& - Pemupukan & 29,7 & 100 \\
& - Pengendalian Gulma & 69,7 & 100 \\
& - Penyakit & 46,5 & 100 \\
\hline & - Waktu Panen dan penyulingan & 35,7 & $\mathbf{1 0 0}$ \\
\hline
\end{tabular}

Tabel 1 menunjukkan bahwa animo petani dalam mendapatkan pengetahuan dan keterampilan dalam pelaksanaan budidaya tanaman nilam sangat tinggi. Selain itu, pelaksanaan penyuluhan dan pengenalan budidaya dilaksanakan di lapangan dimana tanaman nilam tersebut ditanam. Keuntungan lain dari kegiatan pembelajaran sambil praktik, mendorong petani lebih memahami dengan cepat dibanding dengan hanya dilakukan di ruangan atau berupa simulasi. Hasil kuesioner dengan uji Chi Kuadrat $\left(\chi^{2}\right)$ menunjukkan adanya perbedaan yang nyata pemahaman tentang budidaya tanaman nilam sebelum dan sesudah dilaksanakan penyuluhan melalui demplot tanaman, yaitu ditunjukkan dengan nilai hitung pada taraf uji 5\% sebesar 5.36 dengan nilai Chi Kuadrat tabel 3.481. Berdasarkan hasil uji Chi Kuadrat $\left(\chi^{2}\right)$, petani lebih memahami arti pengelolaan tanaman berdasarkan umur tanaman. Hal ini berarti bahwa konsep budidaya berdasarkan keekologian atau spesifik lokasi dalam pertanaman budidaya tanaman nilam mutlak diperhatikan. Selain itu, adanya peningkatan pemahaman petani terhadap pengelolaan tanaman nilam di lapangan didukung dengan dibuatnya buku pedoman budidaya tanaman nilam. Buku pedoman tersebut sebagai acuan dalam melaksanakan aktifitas penanganan tanaman di lapangan.

Secara ringkas penanganan tanaman di lapangan adalah dengan pengadaan bibit/setek, media pembibitan dengan polybag dengan media top soil dan pupuk kandang dengan perbandingan 2:1, pembibitan dilakukan dengan naungan dengan masa waktu 4 minggu, penanaman dilakukan menggunakan jarak tanam $80 \mathrm{~cm} \mathrm{x} 50 \mathrm{~cm}(25.000$ tanaman/ha). Dosis pupuk, yaitu $200 \mathrm{~kg}$ Urea, $100 \mathrm{~kg}$ untuk masing-masing TSP dan $\mathrm{KCl}$, aplikasi dilakukan dua minggu setelah tanaman dan saat tanaman telah berumur dua bulan. Adapun jenis hama dan penyakit yang harus diwaspadai (Dirjenbun, 2012; Nuryani, 2006; Rosman., dkk, 1998; Asman., dkk, 1998) adalah, Penyakit layu bakteri disebabkan oleh 
bakteri Ralstonia solanacearum, nematoda antara lain Pratylenchus brachyurus, Meloidogyne incognita, Radhopolus similis, sedangkan penyakit budog diperkirakan disebabkan oleh virus. Hama yang menyerang tanaman antara lain; belalang, kutu daun tungau dan ulat daun. Belalang dan ulat daun dapat menyebabkan tanaman gundul sehingga menurunkan produksi (terna). Serangan kutu daun dan tungau dapat menyebabkan daun menggulung dan berkeriput (keriting), sehingga mempengaruhi pertumbuhan tanaman. Serangan hama menyebabkan produksi menurun terutama karena pada umumnya bagian tanaman yang banyak diserang adalah daun. Hama penyakit yang menyerang pada petanaman saat demplot adalah penyakit budog, pengendaliannya dengan eradikasi, yaitu dengan mencabut tanaman yang terserang lalu di benamkan dalam tanah. Model pelaksanaan demplot (Gambar 2), dan jenis kegiatan yang dilaksanakan berdasarkan umur tanaman disajikan pada Tabel 2. Aktifitas petani saat penanaman nilam di lapangan disajikan pada Gambar 1.

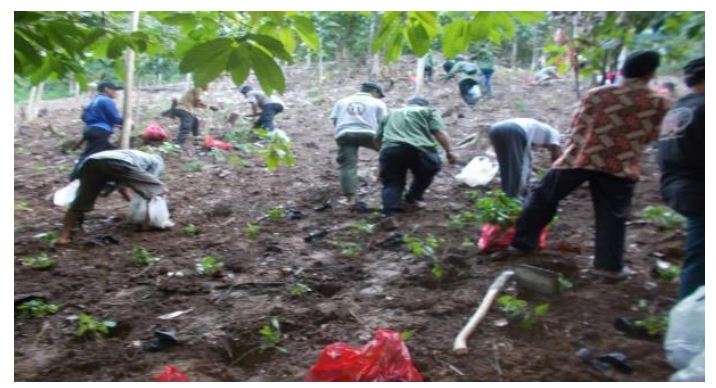

Gambar 1. Aktifitas Penanaman Nilam di Lapangan

Sedang model pertanaman nilam dengan tanaman kehutanan dan tanaman kakao/kopi sebagai tanaman MPTS (Multy Purpose Tree Species) disajikan pada Gambar 2 .

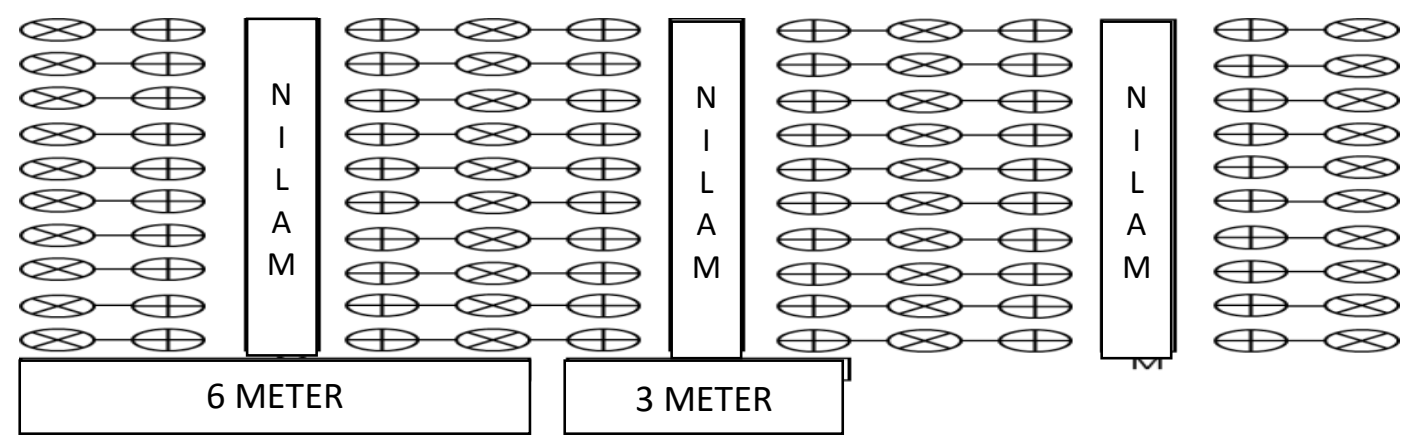

$$
\begin{aligned}
\text { Keterangan }= & \mathrm{x} \text { Tanaman Kayu2an } \\
& + \text { Tanaman Kakao } / \text { Kopi }
\end{aligned}
$$

Gambar 2. Model Pertanaman Nilam dan Tanaman Kayu dan Kakao/Kopi.

Berdasarkan hasil penyulingan diperoleh rendemen antara 2,14-3,10 persen, dengan demikian bila dikonversi ke hasil brangkasan yang diperoleh, maka hasil minyak atsiri nilam yang diperoleh sekitar $350-385 \mathrm{~kg}$, bila harga di pasaran saat ini $\mathrm{Rp}$ $500.000 / \mathrm{kg}$ (harga tersebut berfluktuatif dari $\mathrm{Rp} 250.000-750.000 / \mathrm{kg}$ ), maka pendapatan petani dalam satu hektar adalah 175.000.000-192.500.000 dengan biaya produksi 125.000.000 dalam kurung waktu 4-6 bulan (satu musim tanam) dengan keuntungan bersih sebesar Rp 58.750.000/ha atau Rp 9.791.000/ha/bulan. 
Tabel 2. Schedule Pengelolaan Budidaya Pertanaman Nilam

\begin{tabular}{|c|c|c|c|c|c|c|c|c|}
\hline \multirow{2}{*}{ No } & \multirow{2}{*}{ Kegiatan } & \multicolumn{6}{|c|}{ Bulan } & \multirow{2}{*}{ Keterangan } \\
\hline & & 1 & 2 & 3 & 4 & 5 & 6 & \\
\hline 1 & $\begin{array}{l}\text { Pembabatan semak atau gulma } \\
\text { (minggu III) }\end{array}$ & $\mathbf{x}$ & & & & & & $\begin{array}{l}\text { Pembabatan dilakuakn guna } \\
\text { memudahkan pelaksanaan } \\
\text { pembajakan }\end{array}$ \\
\hline 2 & $\begin{array}{l}\text { Pengolahan dan penggemburan tanah } \\
\text { (minggu I lahan dibiarkan terbuka } \\
\text { selama seminggu) }\end{array}$ & $\mathbf{x}$ & & & & & & $\begin{array}{l}\text { Selain pengolahan tanah juga } \\
\text { dibuat saluran drainase }\end{array}$ \\
\hline 3 & $\begin{array}{l}\text { Pembuatan bedengan dan perataan } \\
\text { tanah pertanaman di lapangan } \\
\text { (minggu III) }\end{array}$ & $\mathbf{x}$ & & & & & & $\begin{array}{l}\text { Waktu tersebut juga dilakukan } \\
\text { pemberian pupuk organik } \\
\text { sebanyak } 20 \text { ton/ha. }\end{array}$ \\
\hline 4 & $\begin{array}{l}\text { Pengajiran dan pembuatan lubang } \\
\text { tanam (minggu iv) }\end{array}$ & $\mathbf{x}$ & & & & & & $\begin{array}{l}\text { Guna mengoptimalkan populasi } \\
\text { persatuan luas tanam }\end{array}$ \\
\hline 5 & $\begin{array}{l}\text { Penanaman (dalam minggu tersebut } \\
\text { telah turun hujan minimal dengan } \\
\text { curah hujan }>20 \mathrm{~mm} \text { ) bibit yang } \\
\text { ditanam adalah bibit polybag dan } \\
\text { dilakukan pemupukan urea pertama. }\end{array}$ & & $\mathbf{x}$ & & & & & $\begin{array}{l}\text { Bila hujan tidak turun hingga } 7 \\
\text { hari setelah tanam dianjurkan } \\
\text { dilakukan penyiraman. }\end{array}$ \\
\hline 6 & $\begin{array}{l}\text { Pengendalian hama daun (dua minggu } \\
\text { setelah tanam) dan waktu yang } \\
\text { bersamaam dilakukan pengamatan } \\
\text { gejalah penyakit budog. }\end{array}$ & & $\mathbf{x}$ & & & & & $\begin{array}{l}\text { Insektisida yang digunakan } \\
\text { adalah kontak dengan } \\
\text { konsentrasi 2cc/liter air. Untuk } \\
\text { mencegah serangan hama daun } \\
\text { pada daun yang telah mulai } \\
\text { muncul }\end{array}$ \\
\hline 7 & $\begin{array}{l}\text { Pembunbunan tanaman dilakukan } \\
\text { pada minggu ke tiga setelah tanam } \\
\text { sekaligus pengendalian gulma tahap } \\
\text { pertama }\end{array}$ & & $\mathbf{x}$ & & & & & $\begin{array}{l}\text { Untuk menghindari rebahnya } \\
\text { tanaman }\end{array}$ \\
\hline 8 & Pemupukan bulan ke dua & & & $\mathbf{x}$ & & & & $\begin{array}{l}\text { Dibenamkan sekitar perakaran } \\
\text { tanaman }\end{array}$ \\
\hline 9 & $\begin{array}{l}\text { Menyanggah tanaman yang rebah } \\
\text { serta memangkas cabang yang tidak } \\
\text { tumbuh normal ( pertumbuhan tidak } \\
\text { normal) }\end{array}$ & & & $\mathbf{x}$ & & & & $\begin{array}{l}\text { Agar tanaman tidak mudah } \\
\text { robah }\end{array}$ \\
\hline 10 & Penegndalian hama dan penyakit & & & & $\mathbf{x}$ & & & Pengendalian hama daun \\
\hline 11 & Pengendalian gulma tahap ke dua & & & & $\mathbf{x}$ & & & $\begin{array}{l}\text { Dilakukan sebelum tanaman } \\
\text { menutup seluruh areal }\end{array}$ \\
\hline 12 & $\begin{array}{l}\text { Pengairan, yaitu dilakukan } \\
\text { penyiraman bila tiga minggu tidak } \\
\text { turun hujan }\end{array}$ & & & & $\mathbf{x}$ & & & $\begin{array}{l}\text { Untuk mencegah pertumbuhan } \\
\text { vegetative tidak optimal }\end{array}$ \\
\hline 13 & Pemupukan tahap ke tiga & & & & $\mathbf{x}$ & & & $\begin{array}{l}\text { Pemupukan dianjurkan setelah } \\
\text { turun hujan }\end{array}$ \\
\hline 14 & Pemupukan tahap ke empat & & & & & $\mathbf{x}$ & & $\begin{array}{l}\text { Penggunaan pestisida tidak } \\
\text { dianjurkan hingga panen }\end{array}$ \\
\hline 15 & Panen & & & & & $\mathbf{x}$ & & $\begin{array}{l}\text { Dianjurkan pada sore hari dan } \\
\text { tidak turun hujan }\end{array}$ \\
\hline 16 & $\begin{array}{l}\text { Penanganan brangkasan hasil panen } \\
\text { (brangkasan tidak disimpan sampai } 1 \\
\text { bulan) }\end{array}$ & & & & & $\mathbf{x}$ & $\mathbf{x}$ & $\begin{array}{l}\text { Bila belum disuling disimpang } \\
\text { dalam kondisi kering. }\end{array}$ \\
\hline 17 & Penyulingan & & & & & & $\mathbf{x}$ & Brangkasan dicacah \\
\hline
\end{tabular}

Pelaksanaan penyulingan dilakukan setelah panen, yaitu dengan mencacah brangkasan kemudian dimasukan ke dalam tangki, brangkasan sebelum dimasukkan ke dalam tangki ditimbang untuk mengetahui rendemen minyak yang dihasilkan (Gambar 3). 

Pengrebusan brangkasan dilakukan selama 3-4 jam dengan suhu $105^{\circ} \mathrm{C}-130^{\circ} \mathrm{C}$, alat suling yang digunakan disajikan pada Gambar 4.

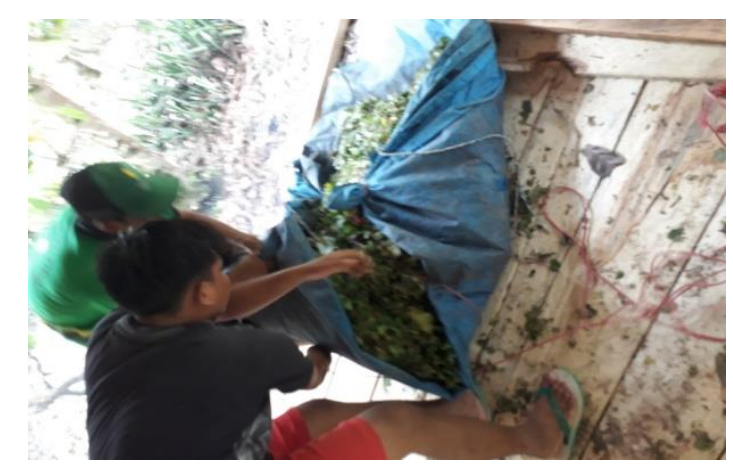

Gambar 3. Brangkasan Nilam

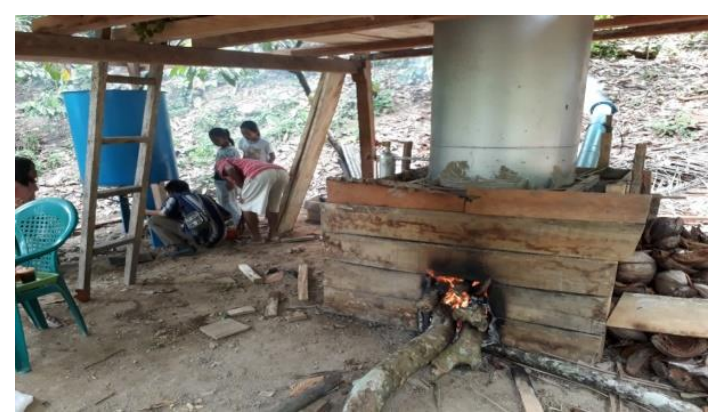

Gambar 4. Alat suling Nilam

Hasil penyulingan minyak nilam yang diperoleh adalah dengan rendemen 2,14-3,10 persen, minyak atsiri nilam yang diperoleh disajikaan pada Gambar 5.

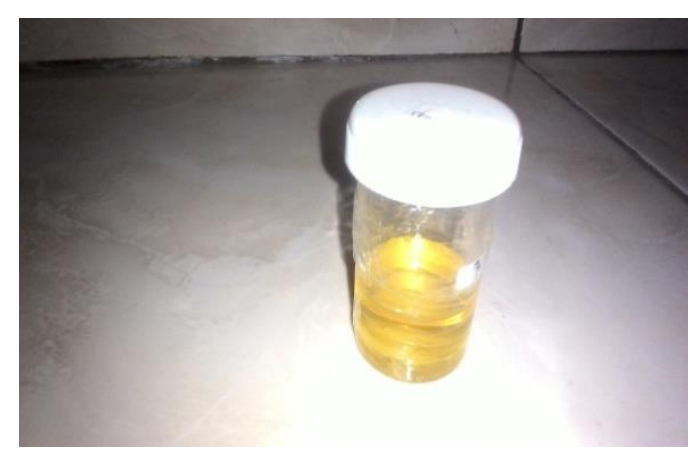

Gambar 5. Minyak Atsiri Nilam 


\section{KESIMPULAN DAN SARAN}

\section{Kesimpulan}

1. Pelaksanaan pengabdian kepada masyarakat, berupa Ipteks bagi masyarakat (PPDM) yang telah dilaksanakan memberikan efek positip, yaitu pengetahuan petani peserta sebelum pelaksanaan kegiatan baru mencapai $34,21 \%$ dan setelah pelaksanaan selesai pengetahuan tersebut meningkat menjadi $100 \%$.

2. Pelaksanaan penyuluhan dilakukan mengikuti perkembangan pertumbuhan tanaman. Berdasarkan kegiatan tersebut diperoleh hasil terna panen sejumlah 15,34 ton/ha. Adapun kegiatan budidaya yang dilaksanakan meliputi, pelaksanaan pembibitan, persipan lahan, penanaman tanaman nilam, pemupukan, pengendalian gulma, pengendalian hama dan penyakit, serta panen dan penyulingan.

3. Berdasarkan uji Chi Kuadrat $\left(\chi^{2}\right)$ menunjukkan adanya perbedaan yang nyata pemahaman tentang budidaya tanaman nilam sebelum dan sesudah dilaksanakan penyuluhan dan demplot tanaman, yaitu ditunjukkan dengan nilai hitung pada taraf uji 5\% sebesar 4,21 dengan nilai Chi Kuadrat pada t tabel 3.48.

4. Keuntungan bersih yang diperoleh petani sebesar $\mathrm{Rp} 58.750 .000,00$ selama enam bulan atau $\mathrm{Rp} 9.791 .000 /$ bulan/ha.

\section{Saran}

Berdasarkan hasil pelaksanaan kegiatan pengabdian kepada masyarakat, yang berupa Ipteks bagi Program Pengembangan Desa Mitra (PPDM), telah dilakukan dan terlaksana dengan baik. Selanjutnya, untuk mendapatkan objek yang lebih baik, sebaiknya untuk melaksanakan kegiatan penanaman tanaman atau demplot dilaksanakan awal tahun, yaitu bulan Februari karena waktu tersebut masuk dalam musim hujan.

\section{DAFTAR PUSTAKA}

Asman, A, Ester M, Adhi, dan D, Sitepu, 1998, Penyakit layu, budok dan penyakit lainnya serta strategi pengendaliannya, Monograf nilam, 5:84-88.

Dirjebun, 2012, Peningkatan Produksi, Produktivitas dan Mutu Tanaman Semusim. Pedoman Teknis Pelaksanaan Penanaman Tanaman Nilam Tahun 2012, Direktorat Jenderal Perkebunan Kementerian Pertanian Republik Indonesia.

KPHL Pesawaran, 2014, Demografi Hutan Lindung Register 20 Kabupaten Pesawaran.

Rosman, R, Emmyzar, dan pasril Wahid, 1998, Karakteristik lahan dan iklim untuk perwilayahan pengembangan, Monograf nilam, 5:47-54.

Tahir, M, dan M, Rofiq, 2015, Peningkatan Mutu Genetik dan Keragaman Hayati Nilam Aceh Lokal Lampung Sebagai Tanaman Tropis Melalui Pendekatan Teknologi Molekuler, Tidak Dipublikasikan.

Tahir, M, Ersan, dan Riniarti D, 2017, Seleksi Produksi Bibit Mutan Nilam Unggul Hasil Iradiasi Sinar Gamma dengan Teknologi Marker Assisted Breeding di Provinsi Lampung, Tidak dipublikasikan.

Nuryani, Yang, 2006, Budidaya Tanaman Nilam (Pogostemon cablin Benth), Balai Penelitian Tanaman Rempah dan Aromatika, Pusat Penelitian dan Pengambangan Perkebunan Badan Penelitian dan Pengenbangan Pertanian Bogor. 